\title{
Metabolic changes in early lactation and impaired reproductive performance in dairy cows
}

\author{
Ruurd JORRITSMA $^{\mathrm{a} *}$, Theo WENSING ${ }^{\mathrm{a}}$, Theo A.M. KRUIP ${ }^{\mathrm{b}}$, \\ Peter L.A.M. $\operatorname{Vos}^{\mathrm{a}}$, Jos P.T.M. NOORDHUIZEN ${ }^{\mathrm{a}}$ \\ a Department of Farm Animal Health, Ruminant Health Unit, Utrecht University, PO Box 80151, \\ NL-3508 TD, Utrecht, The Netherlands \\ ${ }^{\mathrm{b}}$ Deparment of Genetics and Reproduction, Institute for Animal Health and Science, PO Box 65, \\ NL-8200 AB, Lelystad, The Netherlands
}

(Received 17 January 2002; accepted 9 July 2002)

\begin{abstract}
This review addresses the suggestion that the decline in dairy reproductive performance, as increasingly observed these days, may be due to a hampered process of metabolic adaptation in early lactating cows. In our opinion, adaptation to the negative energy balance is a gradual process. Because almost all cows do adapt in the long run, it is not possible to classify animals as adapted or non-adapted. The use of risk factors is more appropriate in this case and is discussed in this review. Among them are the body condition score and its derivatives, feed intake, the calculated negative energy balance, and metabolic parameters like the plasma concentration of insulin or the triacylglycerol content in the liver. Moreover, factors that play a role in the link between declined reproductive performance and the metabolic situation of the cow during the early lactating period are discussed. Among these are insulin, insulin-like growth factors, leptin, neuropeptide Y, nonesterified fatty acids, thyroïd hormones, urea, and ammonia.
\end{abstract}

\section{fertility / dairy / periparturient metabolic adaptation / physiopathology / periparturition}

\section{Table of contents}

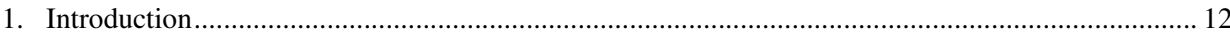

2. Negative energy balance and adaptation: definition, quantification and risk factors ..................... 12

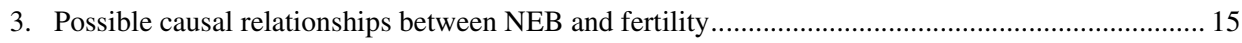

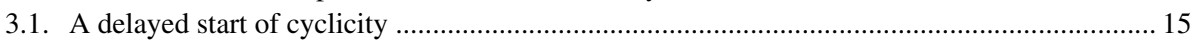

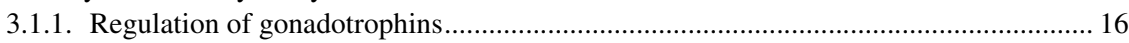

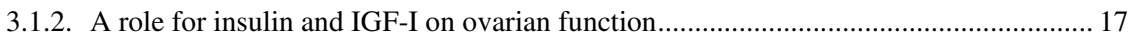

3.1.3. A role for thyroid hormones .................................................................................. 19

3.2. Effects on quality of the oocyte and the corpus luteum ...................................................... 19

3.2.1. A role for IGF-I........................................................................................... 19

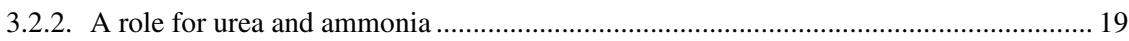

3.2.3. A role for non-esterified fatty acids ........................................................................... 20

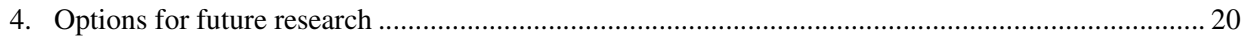

*Correspondence and reprints

Tel.: (31) 30253 1248; fax: (31) 30252 1887; e-mail: R.Jorritsma@vet.uu.nl 


\section{INTRODUCTION}

In the dairy industry, fertility is crucial for the genetic improvement in a herd and the replacement of (un-) voluntarily culled cows. Therefore, both farmers and researchers have paid much attention to decreased fertility in dairy cows $[17,77$, 97]. Impaired fertility has a multifactorial background. Factors that are related with impaired fertility are for example the imperfection of management leading to a diminished estrus detection $[27,67,72$, 103] further hampered by an inadequate cow identification system and record keeping [11], the diminished amount of time spent per animal due to intensification [76], the use of semen from sub-fertile bulls [74], the insemination of cows too early after parturition leading to fewer cycles preceding the first insemination of the cow [22], the absence of an estrus enhancing sexually active group (SAG) [2], the age composition of the herd [51], the health of the cow in general $[5,6,56]$, and the housing conditions of the cows $[11,30]$.

Another factor, not necessarily completely separated from the afore mentioned factors, is the presence of comprehensive metabolic changes around parturition and in early lactation. These metabolic changes, evoked by the difference between energy uptake and energy requirements, frequently referred to as negative energy balance (NEB), call for a considerable adaptive physiological capacity of the cow. Both the metabolic changes and the NEB as such may have repercussions on subsequent fertility.

Some epidemiological studies have been published about this subject. In one of these studies an association between the extent of the calculated NEB and the time between parturition and first ovulation was found [15]. In other studies, the amounts of triacylglycerol in the liver were associated with the time to first heat and the time to conception [55, 58, 77, 80] and larger losses in body condition score (BCS) in the first month post partum was associated with decreased likelihood for conception [27]. No clear evidence exists for the suggestion that the higher milk production as such has an important effect on conception $[34,38]$. Furthermore, suggestions are made that lowered LH pulse frequency in cows facing a large difference between energy uptake and energy requirements, could be responsible for a delay in the onset of ovarian activity and that nonesterified fatty acids may have detrimental effects on, among others, ovarian function $[20,48,85]$.

This review addresses the NEB and the processes of physiological adaptation to the NEB. Also, possible causal relationships between these processes and fertility will be discussed, followed by options for further research in this field.

\section{NEGATIVE ENERGY BALANCE AND ADAPTATION: DEFINITION, QUANTIFICATION AND RISK FACTORS}

During early lactation, the energy requirements for milk production and maintenance of a dairy cow exceed the available energy from feed intake. The net shortage in energy resulting from the imbalance between energy input and energy output is called NEB. NEB is usually quantified by calculations, using general assumptions on energy requirements for maintenance, given a certain body weight $[8,16,20]$, and a milk production with a certain composition. Examples of such systems are the NRC system in the US, the VEM system in the Netherlands, and the UFL system in France [98, 101]. However, the underlying assumptions in these systems that are used in the calculation of the NEB, are based on feeding trials. As a result, they will reflect the situation of the average cow under the given circumstances of those trials, which 
was also the objective of such systems. Individual animals are as a rule different from these average cows. These assumptions will therefore not apply to the individual cow, resulting in a more or less incorrect quantification of the actual NEB of these individual animals. Thus, misclassification of animals about the duration and the size of their calculated NEB can be anticipated when such systems are used. Indeed, it has been reported that the systems are sensitive for differences in feed composition and that the accuracy is different for individual cows [14, 96].

Apart from calculating the NEB, it can also be described by a range of metabolic changes arising from NEB.

Cases of cows with severe NEB leading to the fatty liver syndrome illustrate which parameters may change and to what extent this may occur. Such fatty liver cases are consequently characterized by low glucose and insulin, and elevated beta-hydroxybutyric acid (BHBA) and non esterified fatty acid (NEFA) concentrations in early lactation [3, 95]. Similar observations were done in a study observing cows during NEB [20]. Because the amount of stored body fat and the mobilization of fat is reflected in blood leptin concentrations, changes with regard to the concentration of this hormone in early lactation can be anticipated too $[9,33]$. Other hormones that tend to decrease during feed restriction and NEB are thyroid hormones [65] and insulin-like growth factors (IGF) [63]. These changes reflect the adaptational system of the cow which is activated in order to meet the demands for the increasing milk production and maintenance.

Given the complexity of this adaptational system and the number of metabolites involved, it seems impossible to judge whether this metabolic adaptation is, at a certain point in time, successful or not. Adaptation is a gradual process which is different between animals. It is obvious that the majority of cows will in the long run reach the adapted stage, and a rigid final classification of cows in adapted and non adapted at a certain point in time is therefore meaningless. Providing risk factors that can inform about the degree of adaptation contributes to a solution for this problem. Such risk factors may refer to the biochemical, endocrinological, subclinical and clinical characteristics of the cow. Moreover, these factors can be measured at the time of interest, but also during several days or weeks before this time point. So far, no single specific risk factor is known that informs adequately about the degree of adaptation and due to the multifactorial aspect of adaptation, it is unlikely that such a risk factor will be found. Based on literature, it may be expected that a well chosen combination of these factors will enable us to quantify the extent to which a certain cow is challenged to adapt. Because a more extensive challenge requires a more comprehensive adaptation, these factors indicate the risk of being non adapted at a certain time post partum.

An important and frequently used risk factor that challenges the metabolic adaptation of the cow, is the calculated NEB (cNEB). The moment that the energy balance has reached the calculated most negative value, commonly referred to as the nadir of cNEB, occurs on average between 2.5 and 12 days post partum (pp). The equilibrium between energy from feed intake and energy requirements is mostly attained at approximately 72 days pp [20, 23]. Longer lasting or deeper cNEB, makes non adaptation more likely. Thus, risk factors for the degree of the cNEB are consequently also risk factors for non adaptation. Among these are feed intake and milk production.

The level of the cNEB depends to a larger extent on the increase in feed intake than on the increase in milk production $[102,106]$. Butler and Smith showed no strong relationship between cNEB and milk production [17]. These results show that variation in cNEB between cows is a result of differences in feeding management rather than differences in milk 
production. Higher producing cows are more at risk for a deeper NEB, but differences in NEB are for a larger part explained by feeding management $[8,16$, $50,102]$. Concluding, milk production and feed intake are both risk factors for non adaptation, but the latter is more important.

Other risk factors for non adaptation are obtained using body condition scores (BCS) [32]. For example, cows that have a higher BCS during the dry period tend to have a slower increase in dry matter intake during the first weeks post partum, after the drop in feed intake just prior to parturition [40]. They also reach their maximum dry matter intake, that usually occurs between 12 to 16 weeks post partum [23], later in lactation [40]. Also, a less pronounced depression of feed intake around parturition has been related to restricted feeding in the dry period and lower BCS of dry cows $[39,59]$. This means that high BCS during the dry period, results on average in a more severe and probably also longer lasting cNEB in these cows and should therefore regarded as risk factor for non adaptation. Monitoring BCS can also be used to calculate BCS loss during lactation [32, 42]. A characteristic of this easy applicable method is that the outcome of this method may differ between observers. Moreover, Heuer et al. showed that the sensitivity of this method is low: standardized body condition scoring could only detect about $25 \%$ of cows in calculated severe cNEB [49]. The origin of this low sensitivity may be that subtle changes in BCS can not be detected. However, BCS loss always represents the situation of the individual cow, which is in contrast to the calculated cNEB that reflects the situation of the average cow under the same circumstances. Differences between the cNEB of the average cow and the actual or real NEB of a specific cow, may arise from differences in energy utilization. This is possible, because energy efficiency and consequently available energy depends on the feed intake of the animal, but also on the excretion level in faeces and urine and the adaptation of both the ruminal flora [45] and the ruminal papillae [26]. Indeed, evaluations of feed systems like the dutch VEM system are on average good, but large standard deviations do occur $[14,96]$. Concluding, it is likely that BCS as well as rumen adaptation are risk factors for non adaptation. The observation that BCS truly detects only a small proportion of cows in a large cNEB, can be explained by differences in feed utilization as well as by a lack of sensitivity of measuring BCS.

Veerkamp et al. [99] stated that there are probably differences between cows in how they partition or reallocate their energy among various destinations. They came to their conclusion after assessing that differences in energy efficiencies for separate functions, like lactation, maintenance, or fertility, had not been found, but differences in gross energy efficiency (the energy in produced milk divided by the total energy uptake) were frequently reported [99]. An explanation for this, is that there are (genetic) differences between cows in the partitioning of energy among body functions. This so-called reallocation process, which has been suggested for other species as well $[36,57]$, implies that there is variation in the energy partitioning among cows [100]. Following this hypothesis, it is possible that cows with the same milk production and the same amount of available energy may face a different level of actual negative energy balance, because they use less energy for processes like maintenance, fertility, or immunity. Whether this re-allocation process is not only genetical but also plays a role in the adaptation around parturition and early lactation, is unclear. Nevertheless, it should be regarded as risk factor for non adaptation.

Typical changes in some well known metabolic parameters are also used as risk factors for non adaptation. Among these are changes in the concentration of non-esterified fatty acids (NEFA) in blood [18] and the hepatic triacylglycerol 
(TAG) concentration obtained by liver biopsy [55]. Such techniques are very objective and can detect more subtle and actual differences between cows. In resemblance with BCS loss, changes in these two metabolic parameters do also reflect the actual NEB instead of the cNEB, and the adaptation of the individual cow to this actual NEB. Furthermore, they provide information about the balance between the intensity of fat mobilisation and the fat utilization in among others liver metabolism. A persistent high serum NEFA concentration indicates for example that the metabolism of NEFA, notably present in the liver, is not able to keep up with the mobilization of body fat. Also, it results in increased hepatic uptake of NEFA's and consequently in an increased hepatic TAG production. The relation between the plasma NEFA concentration and the amount of TAG accumulated in the liver is different between cows [29, 54]. When this TAG production exceeds the capacity of the liver to excrete TAG in very low density lipoproteins (VLDL), TAG is accumulated in the liver. In fact, a high liver TAG content in the liver indicates a pathobiochemical course of the hepatic NEFA metabolism. TAG accumulation in the liver is an anabolic process that conflicts from a physiological point of view with the catabolic state of the cow [48]. The process comprising of lipolysis, transport of NEFA to the liver, synthesizing of TAG, and accumulating this TAG in the liver costs energy. Furthermore, serious TAG accumulation in the liver decreases a number of crucial liver functions $[78,79,90,91,105]$. Accumulation of TAG in the liver and persistent high NEFA concentrations indicate therefore a poor adaptation to the large energy demands in early lactation. Persistent low blood glucose and insulin concentrations may indicate the same. Thus, a range of metabolic parameters are risk factors of non adaptation.

Summarizing, physiological adaptation to the shortage of energy in early lactation is a complicated process, that proceeds differently between animals. It comprises an integrated adjustment of the cow with regard to, among others, gluconeogenesis, glycogenolysis, protein metabolism, lipolysis, ketogenesis, but also with regard to the ruminal flora and the ruminal papillae. Adaptation is present as soon as essential functions, among which are immunology, maintenance and reproduction, are hampered. Completely adapted cows have used their pathophysiological mechanisms to such an extent that no negative consequences are present (Fig. 1). Therefore, cows can not unambiguously be classified as adapted or non adapted because the majority of the cows will probably adapt in the long run. Concerning the actual adaptational status, several risk factors are however suited to indicate to which extent a certain cow is challenged to adapt and therefore more at risk for being or becoming non adapted in early lactation. The most important ones are feed intake, calculated NEB, BCS derived parameters, and metabolic parameters like liver TAG content, concentrations of blood NEFA, and blood insulin.

\section{POSSIBLE CAUSAL RELATIONSHIPS BETWEEN NEB AND FERTILITY}

What are the possible mechanisms behind the relation between metabolic (non-) adaptation and reproductive performance? Much research is being done in order to investigate the relation between NEB and fertility. We focussed on two major groups:

1. The delayed start of post partum cyclicity.

2. The effect on oocyte quality or corpus luteum quality.

\subsection{A delayed start of cyclicity}

Ovulation and cyclicity are required for successful insemination. Because insemination is for economic reasons desired at 


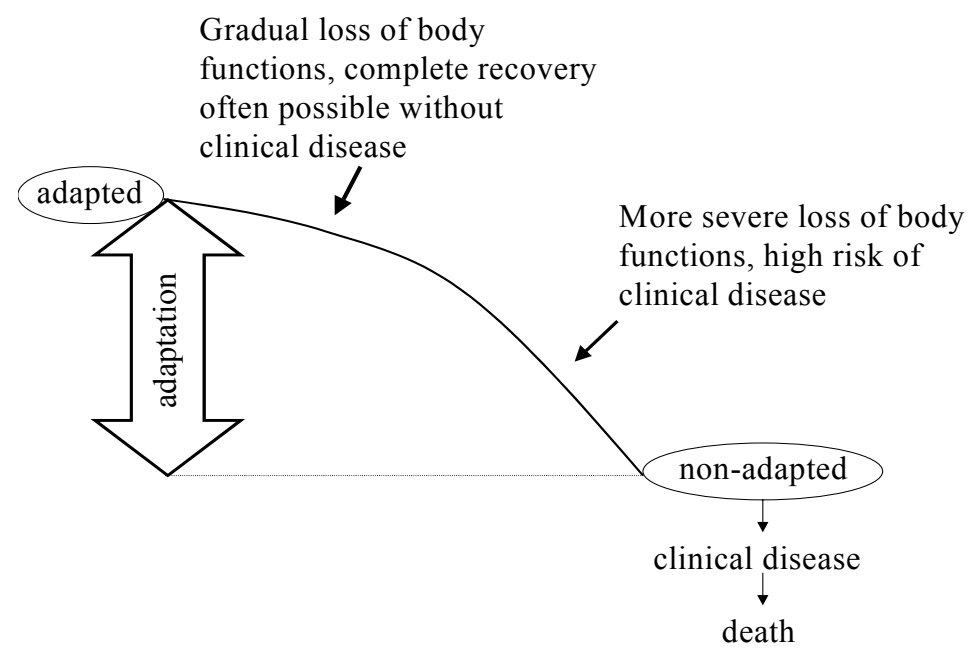

Figure 1. Schematic representation of adaptation.

approximately 2-3 months post partum, cows should ovulate in that period [25]. This is usually reached by the majority of the cows [68]. Moreover, presence of ovarian activity during a certain period before actual insemination is also important, because conception ratio in lactating cows increases when the period of ovarian activity preceding insemination is longer and thus the number of preceding ovulatory cycles is larger [17, 93]. Research is therefore focussed on the question whether nonadaptation resulting from NEB, delays the start of ovarian activity. There are indications from in vivo studies that a lowered energy uptake in early lactation and metabolic parameters that reflect a bad metabolic status of a cow are related with a prolonged interval to first ovulation $[16,35,68]$.

\subsubsection{Regulation of gonadotrophins}

Gonadotrophins play a pivotal role in the reproductive endocrine axis. The establishment of LH pulsatility is responsible for the initiation of cyclicity in, for example, pubertal heifers [82]. The inhibition of LH pulsatility before puberty, and consequently the inhibition of ovarian cyclicity, is in these animals probably due to a negative feedback by estradiol secreted by the ovary. Among the factors that are associated with onset of puberty, attainment of a critical level of body fat is important [82]. This strongly suggests that there are links between the reproductive endocrine system and metabolic status of the animal, which could also apply to non-adaptive cows in early lactation. In particular, LH and not FSH seems to be the limiting factor for resumption of ovarian activity post partum $[60,88]$.

For example, cows with artificially low glucose concentrations, showed less high amplitude LH pulses although the LH pulse frequency and the sensitivity to GnRH remained the same [81]. It is suggested that inadequate glucose supply in ewes may fail the hypothalamic control of pituitary gonadotrophin secretion, but increased glucose supplementation does not guarantee the opposite effect [28]. Similar results were found in beef cattle [88]. Apparently, as long as blood glucose concentrations are within the normal range, $\mathrm{LH}$ pulsatility can be maintained.

The hypothalamo-pituitary ovarian axis can be affected by many neuroendocrine 
factors. Endogenous opioid peptides, related to stress situations, have for example an effect on LH pulsatility in cows and may therefore also be responsible for a certain delay in the onset of ovarian activity post partum [1]. Apart from these effects, we focus on the linkage between the metabolic status and the hypothalamo-pituitary ovarian axis.

Studies in mice revealed a possible candidate for the linking factor between reproduction and the metabolic state of an animal, by the discovery of leptin in ob/ob mice in 1995. In mice, higher basal leptin concentrations reflect higher body fat reserves. Also in cows, changes in energy balance are reflected in fluctuations around their basal leptin concentrations, leading to higher concentrations in case of positive energy balance [9]. Both insulin and glucocorticoids stimulate the leptin concentration in blood and lower the release of neuropeptide Y (NPY) [53]. NPY is known as a potent stimulator of feed intake, but NPY may also be the connection between leptin and the GnRH producing neurons. In addition, the connection between leptin and GnRH may also be fulfilled by pro-opiomelanocortin (POMC) and also direct actions of leptin on GnRH containing neurons have been suggested to explain the effect of leptin on GnRH [21].

Although there is evidence for effects of leptin on rodent reproduction, in vivo studies proving that leptin or NPY plays a role in the regulation of bovine fertility in early lactation are rare. An in vivo study in cows showed that injection of NPY into the third cerebroventricle of ovariectomized cows, caused a decrease in amplitude of tonic LH secretion [94]. Another study of the same group revealed that NPY affected LH pulsatility in a dose-dependent manner, accompanied by changes in the concentration of GnRH in cerebrospinal fluid (CSF) [41].

In sheep, intracerebroventricular leptin injection in ovariectomized ewes did not result in altered LH pulsatility, while lowered feed intake, lowered NPY concentrations in CSF and higher plasma NEFA concentrations were present. The authors suggest that as long as glucose and insulin concentrations are maintained, meaning that adaptation is fairly successful, leptin does not have a direct effect on the neuroendocrine system [47]. A similar explanation may be given for the observation that altered LH pulsatility in rats with different energy balance was not reflected in different leptin concentrations [13]. The above mentioned reports suggest that there is a relative small modulating effect of leptin and NPY on LH pulsatility, which is probably only detectable when comprehensive aberrations from metabolic homeostasis due to negative energy balance do occur. Again, the degree of adaptation, represented by serum glucose and insulin concentrations, seems to be important.

Although LH pulsatility itself is probably not the only factor that determines the onset of ovarian activity in post partum cows, in vivo studies in early lactating dairy cows indeed show an increase in $\mathrm{LH}$ pulsatility as energy balance post partum is changing towards positive values [20].

\subsubsection{A role for insulin and IGF-I on ovarian function}

Given the information that the hypothalamo-pituitary axis is functioning at a certain day post partum, there are other prerequisites necessary for a successful ovulation. Among these is insulin, of which the stimulatory effect on progesterone production has been demonstrated in vitro on granulosa cells from pigs and cows [70]. Another factor seems to be IGF-I, which stimulates follicular growth and has also a clear link with the metabolic status of the cow. Therefore, the effects of insulin and IGF-I are discussed below.

Cows that experience a severe NEB post partum and acquire TAG accumulation in the liver were reported to have lower insulin concentrations [95]. 
Other studies reported that IGF-I concentrations in blood of cows in cNEB due to either fasting or lactating were lower compared to animals in a less negative cNEB $[63,104]$ and that cows selected for high milk production, thereby more at risk of non adaptation, have lower insulin concentrations during peak and mid lactation [10]. Although there are also less promising studies, IGF-I seems one of the reasonable candidates for possible fertility disturbance due to non adaptation.

Before discussing the effects of IGF-I, it should be noted that there is a link between the leptin/NPY system and IGF-I. In fact, growth hormone $(\mathrm{GH})$ stimulates in cows the systemic production, and not the ovarian production, of IGF-I. GH concentration itself is, to some extent, positively affected by elevated NPY concentrations [62]. Indeed, a study in cows showed that injection of NPY in the third cerebroventricle tended to increase pituitary secretion of GH [94]. Concluding, negative energy balance could lead by elevated NPY to elevated GH and IGF-I production, but adaptation to NEB may also result in lowered insulin and consequently lowered GH and IGF-I production. In addition, the stimulating effect of elevated $\mathrm{GH}$ concentrations on IGF-I concentrations is probably diminished or vanished during fasting or NEB, which results in a lowered IGF-I production [64].

Much research has been performed concerning the effect of insulin and IGF-I on ovarian cells in vitro. In vitro studies on the effect on bovine cells, reported that IGF-I and insulin stimulate proliferation, progesterone production and oestradiol production of granulosa cells, and androgen production in theca cells [87]. It is therefore not surprising that insulin and IGF-I receptors are present on various types of ovarian cells, although there are differences in the number of receptors with regard to the stage of the ovarian cycle and the size of the follicle and differences with regard to the observed species [87]. How insulin exactly affects the steroid production is still not completely elucidated, and there might be differences among species with regard to the mechanism [69]. Another important effect of IGF-I (and IGF-II) observed in vitro, is the synergistic action of IGF-I (and IGF-II) with both LH and FSH [62], which is similar to the effect of insulin on the sensitivity of the pituitary to GnRH and the strengthening effect of gonadotrophins on steroid production in humans [69].

The effect of IGF-I in vivo in both follicular fluid and blood is moderated by binding proteins (IGFBP) [62, 87]. The resulting effect of a certain IGF-I concentration together with a certain concentration and composition of IGFBPs is however not known [62]. It is also unclear, whether a high systemic IGF-I concentration always favors reproduction, because studies in mice revealed that instead of systemically produced IGF-I, locally produced IGF-I may be more important for the stimulation of the ovary [62]. This may be important, because the size of the follicle is important for the extent to which follicular IGF-I reflects the systemic concentration of IGF-I [31].

In vivo studies in cows about the effect of higher systemic insulin and IGF-I concentrations on different aspects of fertility are not equivocal. For example, some researchers found an association between plasma insulin concentrations in early lactation and ovulation of the dominant follicle of the first follicular wave [7], whereas a relationship between the plasma insulin concentration and the time to the first ovulation post partum has been confirmed as well refuted [20,44]. Perhaps, this indicates that the process of final follicular maturation is more IGF-I and insulin dependent than the initiation of follicular growth. This suggestion would be in accordance with Armstrong et al. [4], who suggests that there is an important, gonadotrophin independent, stimulating effect of insulin and/or IGF-I on follicular 
growth. This would also argue that insulin and/or IGF-I is more important for stimulation of the growing follicle, rather than for initialization of the process of follicular growth.

Concluding, it is clear that there is still discussion about the effect of IGF-I in combination with a certain level of binding proteins, which makes interpretation of obtained data very difficult. In vivo studies suggest that insulin and a combination of IGF-I and its binding proteins is probably most important for enhancing follicular growth and, as a result, oocyte quality.

\subsubsection{A role for thyroid hormones}

Thyroid hormones tended to decrease during feed restriction [65]. From recent epidemiological studies, thyroid hormones are suggested to play a role in the onset of ovarian activity. For example, concentrations of $\mathrm{T} 3$ and T4 were lower in animals without ovarian activity [92]. Moreover, concentrations of T3 below $1.4 \mathrm{nM}$ were associated with lower concentrations of estradiol and diminished estrus expression [92].

In vitro studies evaluating the effect of thyroid hormones on bovine thecal and granulosa cells, revealed that both $\mathrm{T} 3$ and T4 may have direct stimulatory effects on ovarian function. The major effects were however observed in the presence of insulin or FSH and there were only minor effects on aromatase activity [86]. Apparently, thyroid hormones are part of the complex hormonal mechanism that regulates steroidogenesis in the ovary.

\subsection{Effects on quality of the oocyte and the corpus luteum}

A totally different approach to the observation that non-adaptation diminishes fertility in dairy cows is by observing the quality of the oocytes at the time of insemination. In this approach, the presence of a sufficient number of ovarian cycles is taken for granted, but the quality of the oocytes during a certain stage of lactation is discussed. A hypothetical model that applies to this approach, has been provided by Britt [12]. The underlying assumption of this model is, that the time an antral follicle needs to reach its preovulatory size requires approximately 80 days. Others estimated this time span at about two oestrus cycles, while the time for a follicle to grow from its primordial to ovulatory state was calculated at 180 days [19].

\subsubsection{A role for IGF-I}

In addition to the previous section about IGF-I, the IGF-I and its binding proteins may be important for the quality of the oocyte. The indications from the section above are sustained by observations that deviant follicular development (qualification based on concentration of steroids in follicular fluid) coincide with increased presence of low molecular weight IGFBPs, that are known inhibitors of IGF-I [61]. In these experiments, measurements of IGF were done using a RIA described by Nap et al. and IGFBP's were measured using the slightly modified Western blot analyses described by Hossenlopp et al. [52, 66].

\subsubsection{A role for urea and ammonia}

During adaptation, early lactating dairy cows primarily mobilize body fat. Nevertheless, a limited amount of body proteins will be mobilized as well and can result in elevated plasma urea concentrations. Cows with ruminal flora not adapted to lactational rations may also face higher plasma urea concentrations due to a mismatch between energy and protein at the level of the rumen. In addition, accumulation of triacylglycerides in the liver of cows as occurs during early lactation may result in higher ammonia concentrations, because ureagenesis is inhibited [105]. As a result, especially during early lactation, elevated urea or ammonia concentrations may occur. 
Detrimental effects of both urea and ammonia may occur at different stages of oocyte development, including at the level of the oocyte during the (pre)antral stage of the follicle, but also during fertilization, cleavage, and blastocyst formation.

With regard to ammonia, Sinclair et al. suggested that exposure of oocytes in antral follicles to high levels of ammonia, hampers cleavage and blastocyst formation [83]. Not the actual ammonia concentration during fertilization, cleavage or blastocyst formation was the explanatory variable, but a carry-over effect of the ammonia concentration during the follicular phase was related with the observation. These suggestions are supported by results of Hammon et al. [46].

Focussing on the effect of urea on this process, epidemiological studies showed that milk urea concentrations have limited utility for predicting effects on reproductive performance [43]. More detailed studies found conflicting results with regard to the effects of urea on the fertilization ratio [24, 37]. In contrast, the effects of urea on developmental characteristics of the fertilized oocyte, measured as declined cleavage ratios and lowered blastocyst formation, are similar for different studies [24, 37].

Concluding, effects of urea on fertility are most likely exerted during cleavage and blastocyst formation of the fertilized embryo, whereas effects of ammonia are probably exerted before ovulation. Whether these effects are due to alterations in uterine environment with regard to $\mathrm{pH}$ and ion concentrations, as is suggested by Butler et al. [15], or have another mechanism, is not known. When accepting that urea or ammonia can hamper oocytes during the follicular phase, the question arises whether this is also present during earlier stages of follicular development. This would imply that the effect of high plasma urea concentrations do have a time delayed impact on fertility, thereby directly addressing the hypothesis of Britt [12].

\subsubsection{A role for non-esterified fatty acids}

Elevated NEFA concentrations are an important characteristic of the non-adaptive cow.

It has been suggested that NEFA have a negative impact on fertility $[20,45]$. There are indications that NEFA in vitro have an effect on fertility by depressing progesterone production and granulosa cell proliferation (unpublished observations). To which degree plasma NEFA concentrations are reflected in follicular fluid, is not known. Also, the uptake of NEFA by the ovary during dioestrus is doubtful [71].

In vivo, increased NEFA concentrations are correlated with lowered progesterone concentrations and a decrease in CL weight [104]. Other studies also found lower CL weights in animals during NEB, but did not find lowered plasma progesterone concentrations [75]. If these effects of NEFA on progesterone are present, they may lead to lower pregnancy ratios [89]. There was no effect of NEFA detectable on the conception ratio after first service in high genetic merit cows and on the interval from parturition to first ovulation [73, 84].

Concluding, there is scarce evidence from in vivo studies that NEFA have detrimental effects on fertility. There are also flaws in the theoretical explanation of this observation.

\section{OPTIONS FOR FUTURE RESEARCH}

There is consistent information about a decrease in fertility, measured as prolonged calving intervals or decreased pregnancy ratios. Among others, metabolic changes in early lactation that are consequences of the difference between energy uptake and energy requirements do most likely exert effects on reproduction. There are many suggestions and indications that these changes are related to a postponement of first ovulation and to a diminished 
quality of oocytes that ovulate during a certain period in early lactation. Because a combination of many hormones and metabolic processes are involved in both adaptation and fertility, it is difficult to assess which factors in the adaptational process have a pivotal effect on a certain important aspect of fertility. In other words, even if epidemiological evidence is strong, it is difficult to unravel the pathways that connect fertility problems with adaptation. Possible solutions in order to re-establish fertility especially urge for information about such pathways. Therefore all studies on the relation between fertility and adaptation should be executed with this objective in mind.

An inventory of possible mechanisms, followed by a step by step univariate evaluation of the different factors involved, is required. Although much research in this respect had been conducted, many questions remain to be answered. For example, the effect of NEFA on proliferation and differentiation of luteinizing granulosa cells, as well as its effect on the oocyte during maturation or on embryo development is largely unknown. Also, it needs to be clarified whether NEFA concentrations in the follicular fluid do reflect the actual NEFA concentration in plasma. Promising results require a final evaluation using a multilevel approach in which the importance of each of the univariate factors is weighted within cows.

Characterisation of a cow with respect to the adaptational stage or the extent to which adaptation was successful, is also difficult, resulting in different approaches by different researchers. Likely, also a multilevel approach is needed at this point. This means that risk factors for adaptation should be used at several stages in lactation, as is discussed in the second paragraph of the paper, instead of classifying animals as either being in negative energy balance or being adapted or not. The importance of, for example, reallocation of energy among different body functions during early lactation is one of the underlying univariate questions.

Despite the many unanswered questions, much progress has been made during the last years. The persistent interest in and demands for information about the relation between metabolic adaptation and reproductive performance from both farmers and veterinarians, stresses the importance of the subject and encourages this research. It will hopefully result in quantification of this relation and provide directions to overcome the decrease in reproductive performance.

\section{REFERENCES}

[1] Ahmadzadeh A., Barnes M.A., Pearson R.E., Effect of naloxone on serum luteinizing hormone concentration in anovulatory Holstein cows during the early postpartum period, Domest. Anim. Endocrinol. 15 (1998) 177-181.

[2] Allrich R.D., Estrous behavior and detection in cattle, Vet. Clin. North Am. Food Anim. Pract. 9 (1993) 249-262.

[3] Andrews A.H., Laven R., Maisey I., Treatment and control of an outbreak of fat cow syndrome in a large dairy herd, Vet. Rec. 129 (1991) 216-219.

[4] Armstrong D.G., McEvoy T.G., Baxter G., Robinson J.J., Hogg C.O., Woad K.J., Webb R., Sinclair K.D., Effect of dietary energy and protein on bovine follicular dynamics and embryo production in vitro: associations with the ovarian insulin-like growth factor system, Biol. Reprod. 64 (2001) 1624-1632.

[5] Barkema H.W., Westrik J.D., van Keulen K.A.S., Schukken Y.H., Brand A., The effects of lameness on reproductive performance, milk production and culling in Dutch dairy farms, Prev. Vet. Med. 20 (1994) 249-259.

[6] Bartlett P.C., Ngategize P.K., Kaneene J.B., Cystic follicular disease in Michigan Holstein-Friesian cattle: Incidence, descriptive epidemiology and economic impact., Prev. Vet. Med. 4 (1986) 15.

[7] Beam S.W., Butler W.R., Energy balance and ovarian follicle development prior to the first ovulation postpartum in dairy cows receiving three levels of dietary fat, Biol. Reprod. 56 (1997) 133-142. 
[8] Beam S.W., Butler W.R., Effects of energy balance on follicular development and first ovulation in postpartum dairy cows, J. Reprod. Fertil. Suppl. 54 (1999) 411-424.

[9] Block S.S., Butler W.R., Ehrhardt R.A., Bell A.W., Van Amburgh M.E., Boisclair Y.R., Decreased concentration of plasma leptin in periparturient dairy cows is caused by negative energy balance, J. Endocrinol. 171 (2001) 339-348.

[10] Bonczek R.R., Young C.W., Wheaton J.E., Miller K.P., Responses of somatotropin, insulin, prolactin, and thyroxine to selection for milk yield in holsteins, J. Dairy Sci. 71 (1988) 2470-2479.

[11] Brand A., Varner M.A., Monitoring reproductive performance, in: Brand A., Noordhuizen J.P.T.M., Schukken Y.H. (Eds.), Herd health and production management in dairy practice, Wageningen Academic Publishers, Wageningen, 1996, pp. 283-350.

[12] Britt J.H., Impacts of early postpartum metabolism on follicular development and fertility, Bov. Proc. 24 (1992) 39-43.

[13] Brogan R.S., Mitchell S.E., Trayhurn P., Smith M.S., Suppression of leptin during lactation: contribution of the suckling stimulus versus milk production, Endocrinology 140 (1999) 2621-2627.

[14] Bruinenberg M.H., van der Honing Y., Agnew R.E., Yan T., van Vuuren A.M., Valk H., Energy metabolism of dairy cows fed on grass, Livest. Prod. Sci. 75 (2002) 117-128.

[15] Butler W.R., Nutritional interactions with reproductive performance in dairy cattle, Anim. Reprod. Sci. 60-61 (2000) 449-457.

[16] Butler W.R., Everett R.W., Coppock C.E., The relationships between energy balance, milk production and ovulation in postpartum Holstein cows, J. Anim. Sci. 53 (1981) 742748.

[17] Butler W.R., Smith R.D., Interrelationships between energy balance and postpartum reproductive function in dairy cattle, $\mathrm{J}$. Dairy Sci. 72 (1989) 767-783.

[18] Cameron R.E., Dyk P.B., Herdt T.H., Kaneene J.B., Miller R., Bucholtz H.F., Liesman J.S., Vandehaar M.J., Emery R.S., Dry cow diet, management, and energy balance as risk factors for displaced abomasum in high producing dairy herds, J. Dairy Sci. 81 (1998) 132-139.

[19] Campbell B.K., Scaramuzzi R.J., Webb R., Control of antral follicle development and selection in sheep and cattle, J. Reprod. Fertil. Suppl. 49 (1995) 335-350.

[20] Canfield R.W., Butler W.R., Energy balance and pulsatile LH secretion in early postpar- tum dairy cattle, Domest. Anim. Endocrinol. 7 (1990) 323-330.

[21] Cunningham M.J., Clifton D.K., Steiner R.A., Leptin's actions on the reproductive axis: perspectives and mechanisms, Biol. Reprod. 60 (1999) 216-222.

[22] Darwash O.A., Lamming G.E., Woolliams J.A., The phenotypic association between the interval to post-partum ovulation and traditional measures of fertility in dairy cattle, Anim. Sci. 65 (1997) 9-16.

[23] De Vries M.J., van der Beek S., Kaal-Lansbergen L.M.T.E., Ouweltjes W., Wilmink J.B.M., Modeling of energy balance in early lactation and the effect of energy deficits in early lactation on first detected estrus postpartum in dairy cows, $\mathbf{J}$. Dairy Sci. 82 (1999) 1927-1934.

[24] De Wit A.A., Cesar M.L., Kruip T.A., Effect of urea during in vitro maturation on nuclear maturation and embryo development of bovine cumulus-oocyte-complexes, J. Dairy Sci. 84 (2001) 1800-1804.

[25] Dijkhuizen A.A., Jalvingh A.W., Huirne R.B.M., Galligan D.T., Economic aspects of herd health and production management, in: Brand A., Noordhuizen J.P.T.M., Schukken Y.H. (Eds.), Herd health and production management in dairy cows, Wageningen Academic Publishers, Wageningen, 1996, pp. 57-73.

[26] Dirksen G.H., Liebich H.G., Mayer E., Adaptive changes of the ruminal mucosa and their functional and clinical significance, Bov. Pract. 20 (1999) 116-120.

[27] Domecq J.J., Skidmore A.L., Lloyd J.W., Kaneene J.B., Relationship between body condition scores and conception at first artificial insemination in a large dairy herd of high yielding Holstein cows, J. Dairy Sci. 80 (1997) 113-120.

[28] Downing J.A., Joss J., Scaramuzzi R.J., Ovulation rate and the concentrations of gonadotrophins and metabolic hormones in ewes infused with glucose during the late luteal phase of the oestrous cycle, J. Endocrinol. 146 (1995) 403-410.

[29] Drackley J.K., ADSA Foundation Scholar Award. Biology of dairy cows during the transition period: the final frontier?, J. Dairy Sci. 82 (1999) 2259-2273.

[30] Drost M., Thatcher W.W., Heat stress in dairy cows. Its effect on reproduction, Vet. Clin. North Am. Food Anim. Pract. 3 (1987) 609-618.

[31] Echternkamp S.E., Spicer L.J., Gregory K.E., Canning S.F., Hammond J.M., Concentrations of insulin-like growth factor-I in blood and ovarian follicular fluid of cattle 
selected for twins, Biol. Reprod. 43 (1990) 8-14.

[32] Edmonson A.J., Lean I.J., Weaver L.D., Farver T., Webster G., A body condition scoring chart for Holstein dairy cows, J. Dairy Res. 72 (1989) 68-78.

[33] Ehrhardt R.A., Slepetis R.M., Siegal W.J., Van Amburgh M.E., Bell A.W., Boisclair Y.R., Development of a specific radioimmunoassay to measure physiological changes of circulating leptin in cattle and sheep, J. Endocrinol. 166 (2000) 519-528.

[34] Eicker S.W., Grohn Y.T., Hertl J.A., The association between cumulative milk yield, days open, and days to first breeding in New York Holstein cows, J. Dairy Sci. 79 (1996) 235-241.

[35] El-Din Zain A., Nakao T., Abdel Raouf M., Moriyoshi M., Kawata K., Moritsu Y., Factors in the resumption of ovarian activity and uterine involution in postpartum dairy cows, Anim. Reprod. Sci. 38 (1995) 203-214.

[36] Emmerson D.A., Commercial approaches to genetic selection for growth and feed conversion in domestic poultry, Poult. Sci. 76 (1997) 1121-1125.

[37] Fahey J., Boland M.P., O'Callaghan D., The effect of dietary urea on embryo development in superovulated donor ewes and on early embryo survival and development in recipient ewes, J. Anim. Sci. 72 (2001) 395400.

[38] Fonseca F.A., Britt J.H., McDaniel B.T., Wilk J.C., Rakes A.H., Reproductive traits of Holsteins and Jerseys. Effects of age, milk yield, and clinical abnormalities on involution of cervix and uterus, ovulation, estrous cycles, detection of estrus, conception rate, and days open, J. Dairy Sci. 66 (1983) 11281147.

[39] Garnsworthy P.C., Jones G.P., The influence of body condition at calving and dietary protein supply on voluntary food intake and performance in dairy cows, Anim. Prod. 44 (1987) 347-353.

[40] Garnsworthy P.C., Topps J.H., The effect of body condition of dairy cows at calving on their food intake and performance when given complete diets, Anim. Prod. 35 (1982) 113-119.

[41] Gazal O.S., Leshin L.S., Stanko R.L., Thomas M.G., Keisler D.H., Anderson L.L., Williams G.L., Gonadotropin-releasing hormone secretion into third-ventricle cerebrospinal fluid of cattle: correspondence with the tonic and surge release of luteinizing hormone and its tonic inhibition by suckling and neuropeptide Y, Biol. Reprod. 59 (1998) 676-683.
[42] Gearhart M.A., Curtis C.R., Erb H.N., Smith R.D., Sniffen C.J., Chase L.E., Cooper M.D., Relationship of changes in condition score to cow health in Holsteins, J. Dairy Sci. 73 (1990) 3132-3140.

[43] Godden S.M., Kelton D.F., Lissemore K.D., Walton J.S., Leslie K.E., Lumsden J.H., Milk urea testing as a tool to monitor reproductive performance in Ontario dairy herds, J. Dairy Sci. 84 (2001) 1397-1406.

[44] Gong J.G., Lee W.J., Garnsworthy P.C., Webb R., Effect of dietary-induced increases in circulating insulin concentrations during the early postpartum period on reproductive function in dairy cows, Reproduction 123 (2002) 419-427.

[45] Grummer R.R., Impact of changes in organic nutrient metabolism on feeding the transition dairy cow, J. Anim. Sci. 73 (1995) 2820-2833.

[46] Hammon D.S., Wang S., Holyoak G.R., Effects of ammonia during different stages of culture on development of in vitro produced bovine embryos, Anim. Reprod. Sci. 59 (2000) 23-30.

[47] Henry B.A., Goding J.W., Alexander W.S., Tilbrook A.J., Canny B.J., Dunshea F., Rao A., Mansell A., Clarke I.J., Central administration of leptin to ovariectomized ewes inhibits food intake without affecting the secretion of hormones from the pituitary gland: evidence for a dissociation of effects on appetite and neuroendocrine function, Endocrinology 140 (1999) 1175-1182.

[48] Herdt T.H., Wensing T., Haagsman H.P., van Golde L.M., Breukink H.J., Hepatic triacylglycerol synthesis during a period of fatty liver development in sheep, J. Anim. Sci. 66 (1988) 1997-2013.

[49] Heuer C., Van Straalen W.M., Schukken Y.H., Dirkzwager A., Noordhuizen J.P.T.M., Prediction of energy balance in a high yielding dairy herd in early lactation: model development and precision, Livest. Prod. Sci. 65 (2000) 91-105.

[50] Heuer C., Van Straalen W.M., Schukken Y.H., Dirkzwager A., Noordhuizen J.P.T.M., Prediction of energy balance in high yielding dairy cows with test-day information, J. Dairy Sci. 84 (2001) 471-481.

[51] Hillers J.K., Senger P.L., Darlington R.L., Fleming W.N., Effects of production, season, age of cow, days dry, and days in milk on conception to first service in large commercial dairy herds, J. Dairy Sci. 67 (1984) 861-867.

[52] Hossenlopp P., Seurin D., Segovia-Quinson B., Hardouin S., Binoux M., Analysis of serum insulin-like growth factor binding 
proteins using western blotting: use of the method for titration of the binding proteins and competitive binding studies, Anal. Biochem. 154 (1986) 138-143.

[53] Houseknecht K.L., Baile C.A., Matteri R.L., Spurlock M.E., The biology of leptin: a review, J. Anim. Sci. 76 (1998) 1405-1420.

[54] Jorritsma R., Jorritsma H., Schukken Y.H., Bartlett P.C., Wensing T., Wentink G.H., Prevalence and indicators of post partum fatty infiltration of the liver in nine commercial dairy herds in The Netherlands, Livest. Prod. Sci. 68 (2001) 53-60.

[55] Jorritsma R., Jorritsma H., Schukken Y.H., Wentink G.H., Relationships between fatty liver and fertility and some periparturient diseases in commercial Dutch dairy herds, Theriogenology 54 (2000) 1065-1074.

[56] Kaneene J.B., Miller R., Epidemiological study of metritis in Michigan dairy cattle, Vet. Res. 25 (1994) 253-257.

[57] Klasing K.C., Johnstone B.J., Monokines in growth and development, Poult. Sci. 70 (1991) 1781-1789.

[58] Kruip T.A., Meijer G.A., Rukkwamsuk T., Wensing T., Investigation into the mechanisms of reduction in fertility of high yielding cows. 10th Int. Conf. on Prod. Dis. in Farm An. 1998, pp. 183-190.

[59] Kunz P.L., Blum J.W., Hart I.C., Bickel H., Landis J., Effects of different energy intakes before and after calving on food intake, performance and blood hormones and metabolites in dairy cows, Anim. Prod. 40 (1985) 219-231.

[60] Lamming G.E., Wathes D.C., Peters A.R., Endocrine patterns of the post-partum cow J. Reprod. Fertil. Suppl. 30 (1981) 155-170.

[61] Leemput E.E., Final follicular maturation in the cow and its effects on the developmental potential of the oocyte, thesis, Department of Farm Animal Health, Utrecht University, 1998, pp. 67-84, ISBN 90-393-1640-6.

[62] Lucy M.C., Regulation of ovarian follicular growth by somatotropin and insulin-like growth factors in cattle, J. Dairy Sci. 83 (2000) 1635-1647.

[63] Lucy M.C., Beck J., Staples C.R., Head H.H., De La Sota R.L., Thatcher W.W., Follicular dynamics, plasma metabolites, hormones and insulin-like growth factor I (IGF-I) in lactating cows with positive or negative energy balance during the preovulatory period, Reprod. Nutr. Dev. 32 (1992) 331-341.

[64] McGuire M.A., Bauman D.E., Dwyer D.A., Cohick W.S., Nutritional modulation of the somatotropin/insulin-like growth factor system: response to feed deprivation in lactating cows, J. Nutr. 125 (1995) 493-502.

[65] McGuire M.A., Beede D.K., Collier R.J., Buonomo F.C., DeLorenzo M.A., Wilcox C.J., Huntington G.B., Reynolds C.K., Effects of acute thermal stress and amount of feed intake on concentrations of somatotropin, insulin-like growth factor (IGF)-I and IGF-II, and thyroid hormones in plasma of lactating Holstein cows, J. Anim. Sci. 69 (1991) 2050-2056.

[66] Nap R.C., Mol J.A., Hazewinkel H.A., Agerelated plasma concentrations of growth hormone $(\mathrm{GH})$ and insulin-like growth factor I (IGF-I) in Great Dane pups fed different dietary levels of protein, Domest. Anim. Endocrinol. 10 (1993) 237-247.

[67] Nebel R.L., McGilliard M.L., Interactions of high milk yield and reproductive performance in dairy cows, J. Dairy Sci. 76 (1993) 3257-3268.

[68] Opsomer G., Grohn Y.T., Hertl J., Coryn M., Deluyker H., de Kruif A., Risk factors for post partum ovarian dysfunction in high producing dairy cows in Belgium: a field study, Theriogenology 53 (2000) 841-857.

[69] Poretsky L., Cataldo N.A., Rosenwaks Z., Guidice L.C., The insulin-related ovarian regulatory system in health and disease, Endocr. Rev. 20 (1999) 535-582.

[70] Poretsky L., Kalin M.F., The gonadotropic function of insulin, Endocr. Rev. 8 (1987) 132-141.

[71] Rabiee A.R., Lean I.J., Gooden J.M., Miller B.G., Scaramuzzi R.J., An evaluation of transovarian uptake of metabolites using arterio-venous difference methods in dairy cattle, Anim. Reprod. Sci. 48 (1997) 9-25.

[72] Reimers T.J., Smith R.D., Newman S.K., Management factors affecting reproductive performance of dairy cows in the northeastern United States, J. Dairy Sci. 68 (1985) 963-972.

[73] Reist M., Koller A., Busato A., Kupfer U., Blum J.W., First ovulation and ketone body status in the early postpartum period of dairy cows, Theriogenology 54 (2000) 685-701.

[74] Reurink A., Den Daas J.H.G., Wilmink J.B.M., Effects of AI sires and technician on non-return rates in the Netherlands, Livest. Prod. Sci. 26 (1990) 107-118.

[75] Rhodes F.M., Fitzpatrick L.A., Entwistle K.W., De'ath G., Sequential changes in ovarian follicular dynamics in Bos indicus heifers before and after nutritional anoestrus, $\mathrm{J}$. Reprod. Fertil. 104 (1995) 41-49.

[76] Rougoor C.W., Hanekamp W.J.A., Dijkhuizen A.A., Nielen M., Wilmink J.B.M., Relationships between dairy cow 
mastitis and fertility management and farm performance, Prev. Vet. Med. 39 (1999) 247-264.

[77] Royal M., Darwash A.O., Flint A., Webb R., Woolliams J.A., Lamming G.E., Declining fertility in dairy cattle: changes in traditional and endocrine parameters of fertility, Anim. Sci. 70 (2000) 487-501.

[78] Rukkwamsuk T., Wensing T., Geelen M.J.H., Effect of fatty liver on hepatic gluconeogenesis in periparturient dairy cows, $\mathrm{J}$. Dairy Sci. 82 (1999) 500-505.

[79] Rukkwamsuk T., Wensing T., Geelen M.J., Effect of overfeeding during the dry period on the rate of esterification in adipose tissue of dairy cows during the periparturient period, J. Dairy Sci. 82 (1999) 1164-1169.

[80] Rukkwamsuk T., Wensing T., Kruip T.A., Relationship between triacylglycerol concentration in the liver and first ovulation in postpartum dairy cows, Theriogenology 51 (1999) 1133-1142.

[81] Rutter L.M., Manns J.G., Hypoglycemia alters pulsatile luteinizing hormone secretion in the postpartum beef cow, J. Anim. Sci. 64 (1987) 479-488.

[82] Schillo K.K., Hall J.B., Hileman S.M., Effects of nutrition and season on the onset of puberty in the beef heifer, J. Anim. Sci. 70 (1992) 3994-4005.

[83] Sinclair K.D., Kuran M., Gebbie F.E., Webb R., McEvoy T.G., Nitrogen metabolism and fertility in cattle. II. Development of oocytes recovered from heifers offered diets differing in their rate of nitrogen release in the rumen, J. Anim. Sci. 78 (2000) 2670-2680.

[84] Snijders S.E.M., Dillon P.G., O'Farrell K.J., Diskin M., Wylie A.R.G., O'Callaghan D., Rath M., Boland M.P., Genetic merit for milk production and reproductive success in dairy cows, Anim. Reprod. Sci. 65 (2001) 17-31

[85] Spector A.A., Fletcher J.E., Transport of fatty acid in the circulation, American Physiological Society, Bethesda, MD, 1978, pp. 232-233.

[86] Spicer L.J., Alonso J., Chamberlain C.S., Effects of thyroid hormones on bovine granulosa and thecal cell function in vitro: dependence on insulin and gonadotropins, $\mathrm{J}$. Dairy Sci. 84 (2001) 1069-1076.

[87] Spicer L.J., Echternkamp S.E., The ovarian insulin and insulin-like growth factor system with an emphasis on domestic animals, Domest. Anim. Endocrinol. 12 (1995) 223245.

[88] Stagg K., Spicer L.J., Sreenan J.M., Roche J.F., Diskin M.G., Effect of calf isolation on follicular wave dynamics, gonadotropin and metabolic hormone changes, and interval to first ovulation in beef cows fed either of two energy levels postpartum, Biol. Reprod. 59 (1998) 777-783

[89] Starbuck G.R., Darwash A.O., Mann G.E., Lamming G.E. The detection and treatment of post insemination progesterone insufficiency in diary cows. Occasional publication No. 26, British Society of Animal Science 2 (1999) 447-450.

[90] Strang B.D., Bertics S.J., Grummer R.R., Armentano L.E., Effect of long-chain fatty acids on triglyceride accumulation, gluconeogenesis, and ureagenesis in bovine hepatocytes, J. Dairy Sci. 81 (1998) 728-739.

[91] Strang B.D., Bertics S.J., Grummer R.R., Armentano L.E., Relationship of triglyceride accumulation to insulin clearance and hormonal responsiveness in bovine hepatocytes, J. Dairy Sci. 81 (1998) 740-747.

[92] Suriyasathaporn W., Negative energy balance in postpartum dairy cows: its effect on clinical mastitis and reproductive performance, Ph.D. thesis, Utrecht University, Department of Farm Animal Health, 2000.

[93] Thatcher W.W., Wilcox C.J., Postpartum estrus as an indicator of reproductive status in the dairy cow, J. Dairy Sci. 56 (1973) 608610 .

[94] Thomas M.G., Gazal O.S., Williams G.L., Stanko R.L., Keisler D.H., Injection of neuropeptide Y into the third cerebroventricle differentially influences pituitary secretion of luteinizing hormone and growth hormone in ovariectomized cows, Domest. Anim. Endocrinol. 16 (1999) 159-169.

[95] Van den Top A.M., Wensing T., Geelen M.J., Wentink G.H., van't Klooster A.T., Beynen A.C., Time trends of plasma lipids and enzymes synthesizing hepatic triacylglycerol during postpartum development of fatty liver in dairy cows, J. Dairy Sci. 78 (1995) 2208-2220.

[96] Van der Honing Y., Steg A., Van Es A.J.H., Feed evaluation for dairy cows: tests on the system proposed in the Netherlands, Livest. Prod. Sci. 4 (1977) 57-67.

[97] Van Eerdenburg F.J., Loeffler H.S., van Vliet J.H., Detection of oestrus in dairy cows: a new approach to an old problem, Vet. Q. 18 (1996) 52-54.

[98] Van Es J.H., Feed evaluation for ruminants. I. The systems in use from May 1977 onwards in the Netherlands, Livest. Prod. Sci. 5 (1978) 331-345.

[99] Veerkamp R.F., Selection for economic efficiency of dairy cattle using information on live weight and feed intake: a review, J. Dairy Sci. 81 (1998) 1109-1119. 
[100] Veerkamp R.F., Emmans G.C., Sources of genetic variation in energetic efficiency of dairy cows, Livest. Prod. Sci. 44 (1995) 87-97.

[101] Vermorel M., Feed evaluation for ruminants. II. The new energy systems proposed in France, Livest. Prod. Sci. 5 (1978) 347365.

[102] Villa-Godoy A., Hughes T.L., Emery R.S., Chapin L.T., Fogwell R.L., Association between energy balance and luteal function in lactating dairy cows, J. Dairy Sci. 71 (1988) 1063-1072.

[103] Webster F.B., Lean I.J., Curtis M.A., A case-control study to identify farm factors affecting fertility of dairy herds: multivariate description of factors, Aust. Vet. J. 75 (1997) 262-265.
[104] Yung M.C., Vandehaar M.J., Fogwell R.L., Sharma B.K., Effect of energy balance and somatotropin on insulin-like growth factor I in serum and on weight and progesterone of corpus luteum in heifers, J. Anim. Sci. 74 (1996) 2239-2244.

[105] Zhu L.H., Armentano L.E., Bremmer D.R. Grummer R.R., Bertics S.J., Plasma concentration of urea, ammonia, glutamine around calving, and the relation of hepatic triglyceride, to plasma ammonia removal and blood acid-base balance, J. Dairy Sci. 83 (2000) 734-740.

[106] Zurek E., Foxcroft G.R., Kennelly J.J., Metabolic status and interval to first ovulation in postpartum dairy cows, J. Dairy Sci. 78 (1995) 1909-1920. 